\title{
IN VITRO MORPHOGENIC EVENTS IN CULTURE OF LOTUS CORNICULATUS L. SEEDLING ROOT EXPLANTS
}

\author{
JAN J. RYBCZYŃSKI ${ }^{1}$, MARTA KAROLKOWSKA ${ }^{1}$, ZYGMUNT KACZMAREK ${ }^{2}$, \\ AnNA MiKuŁA ${ }^{1}$, AgNiESZKA FIUK ${ }^{1}$ \\ ${ }^{1}$ Botanical Garden - Center for Biological Diversity Conservation \\ of the Polish Academy of Sciences \\ Prawdziwka 2, 02-976 Warszawa, Poland \\ e-mail: jjryb@ob.neostrada.pl \\ 2 Institute of Plant Genetics of the Polish Academy of Sciences \\ Strzeszyńska 2, 60-573 Poznań, Poland
}

(Received: January 9, 2006. Accepted: February 23, 2006)

\begin{abstract}
The experiments were carried out on Lotus corniculatus (L.) seedling root explants of the cultivar varieties Skrzeszowicka, Caroll A10 and strain 175. Callus formation and shoot regeneration were the major explant response depended mainly on of the studied genotype and used plant growth regulators (PGRs). Primary cortex of proximal and distal end of explant was the most active tissue for callus proliferation. For shoot primordia differentiation deeper zones of cortex took a part. The process of meristematic centre initiation was not uniform and various level of shoot differentiation events were observed not earlier than 3 weeks of culture. Usually, the shoot primordia regeneration began on proximal rather than distal end of the explant. BAP rather than urea derivatives stimulated shoot proliferation in extended cultures. Increasing of BAP and TDZ concentrations brought about the explant polarity and expansion of the meristematic zones. The explant position in root did not have significant influence on the number of regenerated shoots. The cultures only had better bud formation by TDZ when compared to BAP. BAP stimulated bud formation and development of the shoots from them. Short term of TDZ treatment of explants stimulated meristem formation which developed into buds and shoots. CPPU stimulated callus proliferation and bud formation when explants pretreatment was prolonged from 12 to $36 \mathrm{hrs}$.
\end{abstract}

KEY WORDS: birdsfoot trefoil, root explants, callus proliferation, shoot differentiation, plant regeneration, cytokinins.

\section{INTRODUCTION}

Lotus corniculatus (birdsfoot trefoil) belongs to small grain legume of Fabaceae family and its agronomic importance consists on its participation together with fodder grasses in the hay production. Until recently, explants originated from various stage of plant development were employed. It was proved, that birdsfoot trefoil possesses high morphogenic potential described in various tissue culture systems (Rybczyński and Badzian 1987; Rybczyński et al. 1995; Orshinsky and Tomes 1985; Damiani et al. 1985). Root, cotyledon, hypocotyl and protoplast derived calli possessed high morphogenic potential which resulted in formation of prolific shoot regeneration (Ahuja et al. 1983; Niizeki and Saito 1986). Beside experiments describing morphogenic potential of particular seedling explants, there are a number of papers giving evidences of utilisation of these potentials for developing herbicide resistance lines with the help of in vitro selection (Swanson and Tomes 1980; MacLean and Grant 1987; Pofelis et al. 1992).

In the above regeneration systems, an important role was played by purine derived cytokinins, especially BAP. The cytokinin-like activity is presented by urea derivatives, such: thidiazuron (TDZ). In some plant tissue culture regeneration systems TDZ and CPPU are more active than purine derivatives (Mok et al. 1982; Okamato et al. 1978; Takahashi et al. 1978; Thomas and Ketterman 1986; Tegeder et al. 1995). There is evidence that for selected grain legumes, TDZ could stimulate organogenesis (Böhmer et al. 1995) and even somatic embryogenesis (Murthy et al. 1994, 1995). It was proved that other urea derivative, CPPU, played an important role in the control of adventitious buds formation (Fellman et al. 1987; Mohamed et al. 1992), embryogenic callus tissue proliferation of grape and somatic embryos regeneration of peanut (Murthy and Saxena 1994). 
Endogenous plant growth hormones control the development of the seedling during the earlier stage of the in vitro culture. The excise of the explant, from the axis of seedling, resulted in break down of the endogenous PGR streams and particularly the polarity of the explant as it was getting the proximal and distal physiological orientation. Both of the ends of explants collected cytokinins and auxins, respectively. The presence of the plant growth hormones in medium results in various responses of studied explants. The reason of the disorder of the explant polarity could be the expansion of shoot bud differentiation zone as affected by cytokinin activity. In cultures of Chondrilla juncea and Brassica, the effect of the explant position on their root and shoot regeneration was observed. In case of the Convolvulus arvense the shoots were mostly formed on proximal and sporadically on distal ends of the explant. (Kefford and Caso 1972; Lazzeri and Dunwell 1984a; Bonnet and Torrey 1965).

Having in mind the already known morphogenic potential of birdsfoot trefoil, the aim of the paper is to describe the shoot formation in relation of explant position in the seedling root of Lotus corniculatus with the application of selected plant growth regulators using numerous agar media. For better understanding the shoot formation by root explant, the morphogenesis events were studied with application of the cyto-histological and SEM analysis.

\section{MATERIALS AND METHODS}

\section{Media used}

All experiments were carried out using of Murashige and Skoog's medium (1962), called further MS medium. For seeds germination only $0.5 \mathrm{MS}$, half strength of mineral salts concentration of the medium was used. The following plant growth hormones were employed: both BAP and TDZ in concentration 0.0-2.0 mg. $\mathrm{dcm}^{-3}$ and CPPU (0.0-2.0 $\mathrm{mg} \cdot \mathrm{dcm}^{-3}$ ). Additionally, 50, 100 and $150 \mathrm{ml}$ per $\mathrm{dcm}^{-3}$ of coconut water (CW) (Sigma) supplemented media used. All media were adjusted to $\mathrm{pH}=5.8$ and solidified with $0.8 \%$ agar (Sigma). All cultures were maintained in culture chamber with $16 / 8 \mathrm{hrs}$ photoperiod, and light intensity of $75 \mu \mathrm{Em}^{-2} \mathrm{~s}^{-1}$, at temperature $21 \pm 1^{\circ} \mathrm{C}$.

\section{Seed sterilization and seedling culture}

Seeds of three genotypes (Skrzeszowicka, Caroll A10 and strain 175) of Lotus corniculatus were treated with $70 \%$ ethanol for 30 secs and surface sterilised in $10 \%(\mathrm{w} / \mathrm{v})$ "Domestos" bleach for $10 \mathrm{~min}$. followed by five washes of sterile distilled water. After 24 hrs of water imbibitions, seeds were germinated on sterile, moist white paper in sealed plastic petry plates. Later plant material was transferred to glass tube with $30 \mathrm{ml}$ of culture medium and cultures were maintained for next four weeks.

\section{Culture of root explants}

For each plant-growth hormone combination root explants, which originated from 10 seedlings, were cultured for 6 weeks. Explants were placed on medium according to the sequence of position in the root, from proximal to distal end. To omit any meristematic tissue, the culture did not include the first explant directly located at shoot-root junction and the last one possessing root tip meristem. After 6 weeks of culture all explants were transferred to jars or conical flasks with hormone-free medium for the next threefour weeks. This period helped to develop already formed buds and to elongate shoots.

\section{Estimation of plant growth regulators (PGR) effect on seedling root explant response}

The estimation of the PGR effect consists on description of the callus proliferation intensity and counting of the number of shoot primordia and shoots regenerated. To assess the process of the shoot primordium formation, a five step scale of description was used: 0-degree (lack of explant response); $1{ }^{\text {st }}$-degree (lack of primordia differentiation); $2^{\text {nd }}$-degree (weak primordia differentiation $=4$ primordia); $3^{\text {rd }}$-degree (average differentiation of 5-9 primordia) $4^{\text {th }}$-degree (intensive shoot differentiation $>10$ primordia). Callus proliferation intensity was estimated with the application of the four degree scale.

\section{Explant position in root and its shoot formation capability}

The expression of morphogenic response was assessed by the counting of the shoots with the application of following criteria: first three (closely located to shoot-root junction - proximal part), second three (originated from the central part of root) and last three (closely located to the root tip - distal part). For all studied forms, cvs. Skrzeszowicka and Caroll A10 and strain 175, two - factor analyses of variance were performed for the number of regenerated shoots in six various media combinations of BAP (factor A) and in three groups of explants location (factor B).

\section{Scanning electron microscopy (SEM) examination}

To describe the developmental changes leading to shoot primordia formation plant material was selected and analysed with application of SEM. The material was transferred to microporous specimen capsules and fixed by either FAA (mixture of formaldehyde, acetic acid and ethanol) or glutaraldehyde $(2.5 \%$ glutaraldehyde in $0.2 \mathrm{M}$ cacodylate sodium) fixative. After two hours of fixation the plant material was washed $(3 \times 45 \mathrm{~min})$ in $0.1 \mathrm{M}$ cacodylate buffer. For the overnight post-fixation at $+4^{\circ} \mathrm{C}$ the material was transferred to the solution of $1 \% \mathrm{OsO}_{4}$ in $0.2 \mathrm{M}$ cacodylate sodium buffer $(\mathrm{pH}=7.0)$. Later, two washes in $0.2 \mathrm{M}$ cacodylate buffer $(2 \times 15 \mathrm{~min})$ and phosphate buffer $(2 \times 15 \mathrm{~min})$ both with $\mathrm{pH}=7.0$ were applied. For dehydration the samples were embedded in the series of ethanol. In 10-100\% ethanol only fifteen minutes of dehydration were used with the exception of $70 \%$ ethanol in which the plant material was kept for one hour. Ethanol was substituted by acetone with the following mixtures: ethanol and acetone 3:1 (for $30 \mathrm{~min}$.), 1:1 (for $30 \mathrm{~min}$.), 1:3 (for $60 \mathrm{~min}$.). Finally, the samples were twice washed with pure acetone for $30 \mathrm{~min}$ each. The samples were dried at $40^{\circ} \mathrm{C}$ and under the pressure of $1100-1200 \mathrm{lb}$./in ${ }^{2}$ in the presence of $\mathrm{CO}_{2}$ liquid with the application of critical point dryer E3100 JUMBO SERIES II (Polaron Equipment Ltd, England). The samples were coated with gold using Jeol Vacuum Evaporator (Japan). Finally, they were analysed with the help of scanning electron microscope Joel type JSM-S1 (Japan).

\section{Cyto-histological examination}

For histological analysis the plant material was collected at 8th, 12th and 16th day of culture. Fragments of tissue 
were fixed with FAA fixative and later embedded in the series of ethanol for dehydration. Later, $100 \%$ ethanol and xylol in various proportions 1:3, 1:1, 3:1 were used. Finally, the plant material was embedded in paraffin $56^{\circ} \mathrm{C}$ and cut on $10 \mu$ specimens. Specimens were stained with the help of safranin and fast green dyes. At the end of the procedure the specimens were closed with the help of Canadian balsam. Specimen pictures were taken with help of Olympus "Vanox" microscope.

\section{Statistical analysis}

Numerous combinations of plant growth regulators, genotypes, explants and their response in relation to the position in root presented in experiments required various statistical analyses. For each of three genotype: Strzeszowicka and Caroll A10 and strain 175, the one-way analysis of variance with unequal number of observations were used to examine the differences between six medium combinations with respect to the number of regenerated shoots. Two-way analyses of variance were applied for testing differences between the position of explants in seedling root and for testing the hypotheses concerning the interaction medium combinations $\times$ explants' position with respect to the average number of regenerated shoots. Two-way analyses of variance concerning the frequency of occurrence of particular degrees of scale of shoot primordia formation in all medium combinations were also applied. Because most of the values in the experimental data set are small, especially with zeroes present, the $(X+0.5)^{1 / 2}$ transformation, where $\mathrm{X}$ is the original data, was used (Zar 1984). Of course, the analyses of variance and the least squares difference test (LSD test) for testing the contrasts between treatments (in particular the contrasts between the highest mean and the rest) were performed on the transformed data, although the final presentation of the compared means is in the original scale.

Interesting hypotheses concerning independence between two classification criteria i.e. between medium combination supplemented with $\mathrm{BAP}+\mathrm{CM}$ or $\mathrm{TDZ}+\mathrm{CM}$ and the scales of shoot primordia, with respect to frequency of occurrence, were tested by means of the chi-square test. Testing of all hypotheses was made at the significance level 0.05 and 0.01 .

\section{RESULTS}

\section{Cytomorphology of explant response}

The initial response of explants to the media consisted in size increase on both proximal and distal ends. The proximal end proliferated better and formed more callus tissue than the other one. Figure 1 shows, that cells of primary cortex and central cylinder divided and formed meristematic centres. Along of the same explant, centres of the callus tissue proliferation were later observed, too. Initially callus tissue was formed by the uniformed and undifferentiated cells, which later on underwent differentiation as a result of their size (Fig. 2). Primary cortex of proximal and distal end was the most active tissue for callus proliferation. Figure 2 shows, that rhizodermis was not involved in callus formation, but its compact structure only became looser. In shoot primordia differentiation deeper zones of already regenerated tissue took part. The process of meristematic centre initiation was not uniform and not earlier than 3 weeks of culture the various level of differentiation events were observed. Usually, independently of PGRs used, the shoot primordia regeneration began on proximal rather than distal end of the explant. Structures regenerated on the proximal end of explant were markedly ahead of those formed on the opposite end. The transfer of the regenerants to the MS hormone-free medium stimulated overgrowth of primordia and elongation of shoots with two-three distinct internodes and leaves. Figure 3 illustrates the example of differences among explants response on various concentrations of BAP.

\section{Callus proliferation and shoot primordia formation}

The analysis of variance was applied for the study of frequency of the occurrence in the experiments with two factors, the first factor had six combinations of medium and second factor had five degrees of scale of shoot primordia formation. Results of the analyses of variance showed no significant differences between medium combinations supplemented with BAP and BAP $+\mathrm{CM}$ in respects of frequency of occurrence for three studied forms: two cultivars, Skrzeszowicka and Caroll A10 and one strain 175 (Table 1). The significant differences (at least at the 0.05 level) in the frequency of occurrence were observed between the various scales of shoot primordia formation for all medium combinations supplemented with BAP, BAP $+5 \% \mathrm{CM}$, $\mathrm{BAP}+10 \% \mathrm{CM}$ and $\mathrm{BAP}+15 \% \mathrm{CM}$ and for all studied genotypes. The hypothesis of no interaction between medium combination and scales of shoot primordia formation was rejected (at the 0.01 significance level) for combinations supplemented with BAP and BAP $+5 \% \mathrm{CM}$ for cv. Skrzeszowicka, with BAP, BAP $+10 \% \mathrm{CM}$ and $\mathrm{BAP}+15 \% \mathrm{CM}$ for cv. Caroll A10, and with BAP $+5 \% \mathrm{CM}, \mathrm{BAP}+$ $10 \% \mathrm{CM}$ and $\mathrm{BAP}+15 \% \mathrm{CM}$ for the strain 175 (Table 2).

The effect of TDZ and TZD + CM on the response of root explants various interactions of root tissues and growth promoting substances were found. For all combinations of TDZ and TDZ + CM it was found that they are not statistically significant different based on intensity of shoot primordia formation for all studied forms at the level of significance $\alpha=0.05$. However, statistically significantly differences were observed in terms of the frequency of occurrence of particular degree of shoot primordia or all combinations of media supplemented with TDZ $+10 \% \mathrm{CM}$ and $\mathrm{TDZ}+15 \% \mathrm{CM}$ for all studied forms and for medium supplemented with TDZ for var. Skrzeszowicka and Caroll $\mathrm{A} 10$ and medium combination of TDZ $+5 \% \mathrm{CM}$ for var. Caroll A10 and strain 175. At the level of significance $\alpha=$ 0.05 , statistically significant differences in terms of occurrence of particular degree took place in the case of medium combination TDZ $+5 \% \mathrm{CM}$ for var. Krzeszowicka and medium only supplemented with TDZ for strain 175. Interaction between factor A1 (combination of medium) and B1 (the frequency of occurrence of the degree of scale) appeared statistically significant at the level of significance $\alpha=$ 0.01 for medium with growth substance combinations TDZ, TDZ + 5\%CM, TDZ $+10 \% \mathrm{CM}$ for Caroll A10, Skrzeszowicka, and strain 175 , respectively. For the remaining plant growth substance combinations (TDZ and TDZ + $15 \% \mathrm{CM}$ for Skrzeszowicka, TDZ $+5 \% \mathrm{CM}$ and TDZ + $10 \% \mathrm{CM}$ for var. Caroll $\mathrm{A} 10$, and TDZ and TDZ $+5 \% \mathrm{CM}$ for strain 175) interaction between A1 (combination of me- 

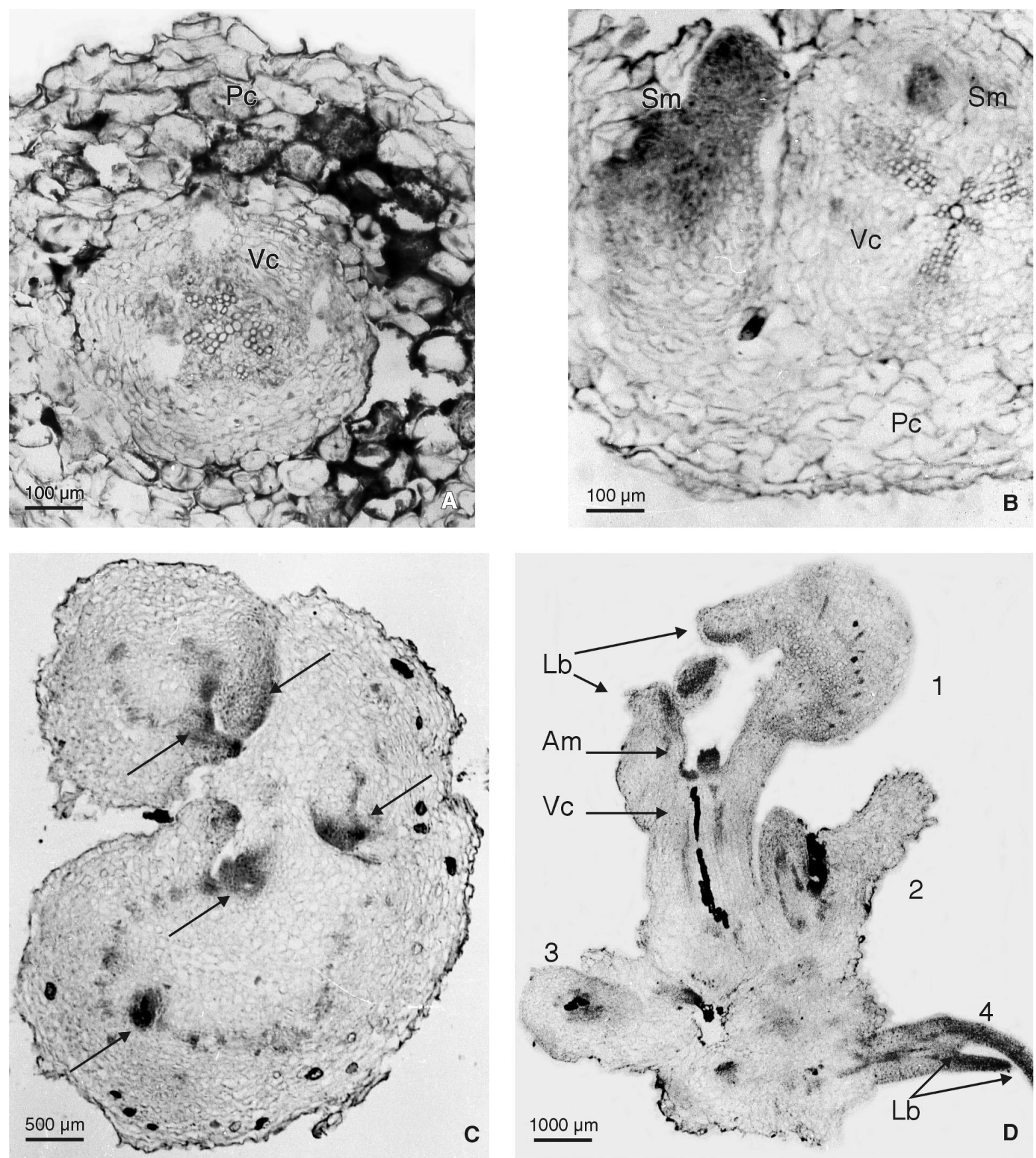

Fig. 1. Cyto-histological analysis of initiation and differentiation of shoots in culture of root seedling explants of $L$. corniculatus (L.).

A - cross section of the root originated from 14-day-old seedling; B - meristem initiation in primary cortex and in vascular cylinder of root explant; C numerous meristematic centres $(\rightarrow)$ formed in proliferating explant; D - long section of already regenerated shoots (1-4).

$\mathrm{Pc}$ - primary cortex; Vc - vascular cylinder; Sm - shoot meristem; Am - apical meristem; Lb - leaf blade

dium) and B1 (the frequency of the occurrence of the degree of scale) appeared non-significant.

In order to illustrate the intensity of shoot primordia formation by particular explant, the percentage of participation of given scale degree for each used medium combination was calculated. The statistical analysis of obtained results allowed to describe the frequency of appearance of given scale degree in the frame of the six BAP and TDZ combinations $\left(0.0 ; 0.1 ; 0.25 ; 0.5 ; 1.0\right.$ and $2.0{\left.\mathrm{mg} . \mathrm{dcm}^{-3}\right)}^{-3}$ and combination of these cytokinins with 5.0; 10.0; and $15.0 \%$ of CM. Explants capable to regenerate not more than 4 and more than 10 primordia appeared in cultures most frequently. The highest average of frequency among studied six combinations compared with others and pairs of averages were selected, there are not statistically significant differences among them on both levels of significance $\alpha=0.01$ and $\alpha=0.05$. From among the six analysed combinations only one was selected, for which average of fre- 

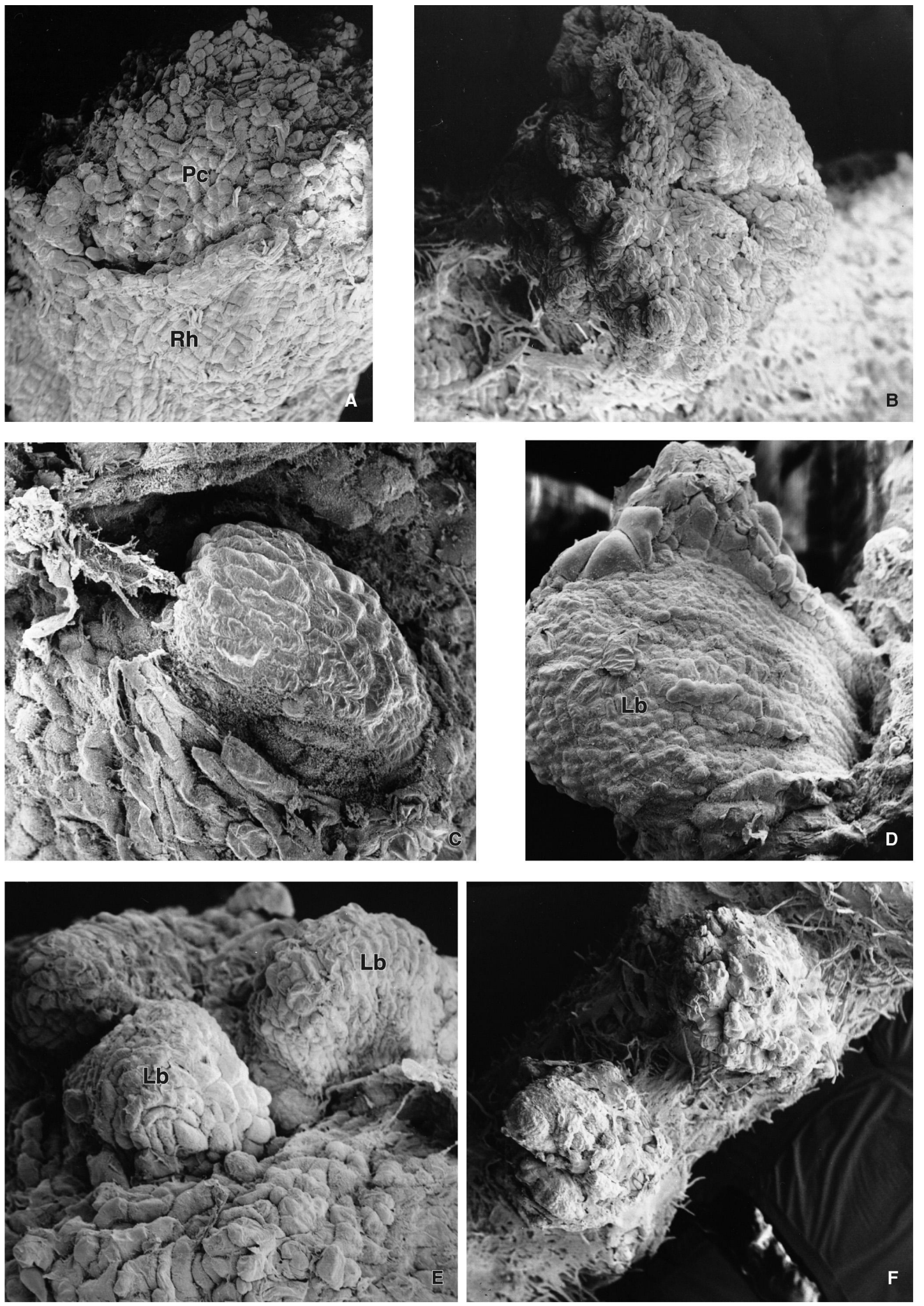

Fig. 2. SEM analysis of initial stages of shoot element differentiation in culture of root seedling explants of Lotus corniculatus (L.) on medium supplemented with cytokinins.

A - initial stage of primary cortex cells proliferation; B - the change of tissue texture in direction to more compact; C - callus tissue differentiation in direction to regenerate leaf blade; $\mathrm{D}$ - already formed leaf blade on proximal end of explant; $\mathrm{E}$-multi-leaf regeneration; $\mathrm{F}$ - getting more morphogenic type of tissue by the centres located in the middle part of explant.

$\mathrm{Pc}$ - primary cortex; $\mathrm{Rh}$ - rhizodermis; Lb - leaf blade 

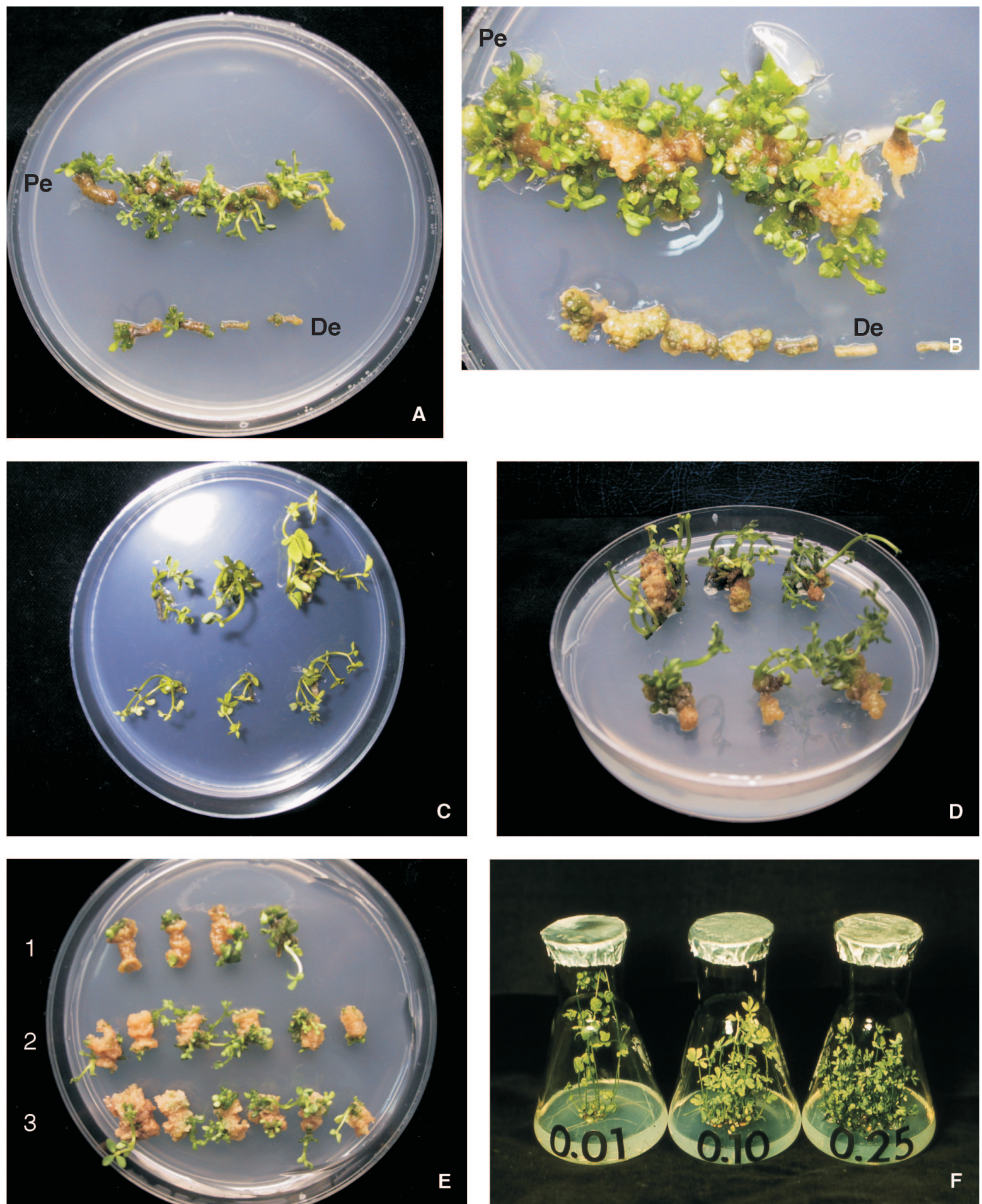

Fig. 3. Shoot regeneration of Lotus corniculatus (L.) in culture of seedling root explant.

A - explants with numerous shoots in 4-week-old culture on MS medium supplemented with $0.1 \mathrm{mg} . \mathrm{dcm}^{-3} \mathrm{BAP}$ (Pe - proximal end; De - distal end); B callus proliferation and leaf regeneration by explants cultured on MS medium supplemented with BAP and coconut milk after 4 weeks of culture (Pe proximal end; De - distal end); C - explant response on $36 \mathrm{hrs}$ of $2.0 \mathrm{mg} . \mathrm{dcm}^{-3} \mathrm{CCPU}$ pre-treatment and later cultured during 8 weeks on hormone-free MS medium; D - explant response on $12 \mathrm{hrs}$ of $10.0 \mathrm{mg} . \mathrm{dcm}^{-3} \mathrm{TDZ}$ pre-treatment and later cultured during 8 weeks on hormone-free MS medium; E - va-

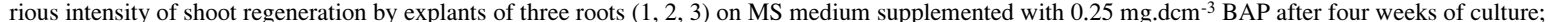
$\mathrm{F}$ - rhizogenesis of shoots originated from various BAP cultures on hormone free MS medium in conical flask. 
TABLE 1. Average numbers of regenerated shoots for six combinations of BAP and results of testing the differences between the best PGR combination and others for each studied form of Lotus corniculatus.

\begin{tabular}{lccc}
\hline \multirow{3}{*}{$\mathrm{mg} . \mathrm{dcm}^{3}$} & \multicolumn{3}{c}{ Genotype } \\
\cline { 2 - 4 } & Skrzeszowicka & Caroll A10 & Strain 175 \\
\hline 0.0 & 2.83 & 2.22 & 0.00 \\
0.1 & $11.17 a$ & $6.56 \mathrm{a}$ & $3.00 \mathrm{a}$ \\
0.25 & $7.61 a$ & 2.89 & $2.00 \mathrm{a}$ \\
0.5 & 5.61 & 2.78 & 0.00 \\
1.0 & 4.67 & 1.00 & 0.00 \\
2.0 & 0.94 & 0.22 & 0.00
\end{tabular}

The average numbers in the same column of regenerated shoots for six medium combinations of BAP labelled with the same letter are the highest and statistically not different at $\alpha=0.05$ significance level. All other values were significantly lower.

quency of the most often occurring degree of the scale was the highest (Table 2).

The callus formation of explants was used as another parameter of culture characterisation. It was presented as the percentage of responding explants. In the majority of cultures, $100 \%$ of explants produced the callus. Explants which did not form callus tissue, only in some cultures were rarely observed.

\section{Explant position}

in the root and its shoot formation capability

The expression of the morphogenic response intensity was described by the number of shoots regenerated during
TABLE 3. Average number of regenerated shoots depending on the positions in seedling root and results of testing the differences between the best explant position and the rest for each form of Locus corniculatus.

\begin{tabular}{lccc}
\hline \multirow{2}{*}{$\begin{array}{l}\text { Location of explants } \\
\text { in seedling root }\end{array}$} & \multicolumn{3}{c}{ Genotype } \\
\cline { 2 - 4 } & Skrzeszowicka & Caroll A10 & Strain 175 \\
\hline Proximal & $6.72 a$ & $3.56 a$ & $1.17 a$ \\
Central & $4.75 a$ & $2.17 a$ & $0.50 a$ \\
Distal & $4.94 a$ & $2.11 a$ & $0.83 a$ \\
\hline
\end{tabular}

The mean numbers of regenerated shoots for three positions of explants labelled with the same letter $a$ in each row are the highest and statistically not different at $\alpha=0.05$ level of significance.

a certain period of the root explant culture. The obtained results were grouped according to the explant position. The results of the analyses were similar for all genotypes. In each case the differences between media combinations were significant at least at the $\alpha=0.05$ level (Table 3).

Among the used media the best one appeared to be the medium supplemented with PGR in concentration of 0.1 $\mathrm{mg} . \mathrm{dcm}^{-3}$. Differences between the best PGR combination and others were statistically significant at the level of significance $\alpha=0.01$ in most cases. Only for cv. Skrzeszowicka and strain 175 significant differences in comparison to the results obtained in cultures of $0.25 \mathrm{mg} \cdot \mathrm{dcm}^{-3} \mathrm{BAP}$ were not observed at the $\alpha=0.05$ level. The hypotheses of no differences between explant location and also the hypotheses of no interaction media combination $\times$ explant posi-

TABLE 2. Frequency of occurrence in five scales of shoot primordia in average for all combinations of BAP, BAP $+\mathrm{CM}, \mathrm{TDZ}$ and TDZ $+\mathrm{CM}$ and results of testing, by the LSD procedure, the differences between the class with the highest frequency and the rest for particular combinations.

\begin{tabular}{|c|c|c|c|c|c|c|}
\hline \multirow{2}{*}{$\begin{array}{l}\text { Genotype } \\
\text { and treatment } \\
\text { combination }\end{array}$} & \multicolumn{5}{|c|}{ Intensity of shoot primordia formation } & \multirow{2}{*}{$\begin{array}{l}\text { PGR concentration in which } \\
\text { the average of frequency } \\
\text { of the most often degree } \\
\text { of scales was shown }\end{array}$} \\
\hline & $\begin{array}{c}\text { 0. - lack } \\
\text { of response }\end{array}$ & $\begin{array}{c}\text { 1. - lack } \\
\text { of primordia }\end{array}$ & $\begin{array}{c}\text { 2. }- \text { number } \\
\text { of primordia } 1-4\end{array}$ & $\begin{array}{c}\text { 3. }- \text { number } \\
\text { of primordia 5-9 }\end{array}$ & $\begin{array}{c}\text { 4. }- \text { number } \\
\text { of primordia }>10\end{array}$ & \\
\hline \multicolumn{7}{|l|}{ Skrzeszowicka } \\
\hline BAP & 0.44 & $2.42 a$ & 1.75 & 0.39 & $3.81 a$ & $1.0 \mathrm{BAP}-6.83$ \\
\hline $\mathrm{BAP}+5 \% \mathrm{CM}$ & 0.00 & $2.33 a$ & 0.44 & $3.94 a$ & 1.89 & $0.5 \mathrm{BAP}-7.33$ \\
\hline TDZ & 0.17 & $3.08 a$ & 0.79 & 0.79 & $2.38 a$ & $1.0 \mathrm{TDZ}-5.75$ \\
\hline $\mathrm{TDZ}+5 \% \mathrm{CM}$ & 1.12 & $3.33 a$ & 1.50 & 1.08 & $3.38 a$ & $1.0 \mathrm{TDZ}-6.75$ \\
\hline $\mathrm{TDZ}+10 \% \mathrm{CM}$ & 0.00 & $4.21 a$ & 0.42 & 1.29 & 0.88 & $0.0 \mathrm{TDZ}-7.75$ \\
\hline $\mathrm{TDZ}+15 \% \mathrm{CM}$ & 0.08 & $4.86 a$ & 0.72 & 2.47 & 0.31 & $0.0 \mathrm{TDZ}-7.17$ \\
\hline \multicolumn{7}{|l|}{ Caroll A10 } \\
\hline TDZ & 0.25 & $2.75 a$ & 1.00 & 1.42 & 1.50 & $0.25 \mathrm{TDZ}-5.50$ \\
\hline $\mathrm{TDZ}+5 \% \mathrm{CM}$ & 0.21 & $3.46 a$ & 0.50 & 0.54 & 1.92 & $0.5 / 1.0 \mathrm{TDZ}-4.75$ \\
\hline $\mathrm{TDZ}+10 \% \mathrm{CM}$ & 0.00 & $3.62 a$ & 0.92 & 1.04 & $2.67 a$ & $0.0 \mathrm{TDZ}-6.25$ \\
\hline $\mathrm{TDZ}+15 \% \mathrm{CM}$ & 0.07 & $4.03 a$ & 1.37 & 1.10 & 1.50 & $0.0 \mathrm{TDZ}-6.00$ \\
\hline \multicolumn{7}{|l|}{ Strain 175} \\
\hline BAP & 0.08 & 3.70 & 0.17 & 1.00 & $6.00 a$ & $0.25 \mathrm{BAP}-12.50$ \\
\hline $\mathrm{BAP}+5 \% \mathrm{CM}$ & 0.00 & $4.17 a$ & 1.56 & 2.06 & 2.28 & $0.1 \mathrm{BAP}-9.67$ \\
\hline $\mathrm{BAP}+10 \% \mathrm{CM}$ & 1.22 & 4.11 $a$ & 1.28 & 1.28 & 1.67 & $0.5 \mathrm{BAP}-7.33$ \\
\hline $\mathrm{BAP}+15 \% \mathrm{CM}$ & 0.05 & $1.78 a$ & 0.22 & 1.28 & $2.94 a$ & $2.0 \mathrm{BAP}-5.33$ \\
\hline TDZ & 0.44 & $1.78 a$ & $2.06 a$ & 0.78 & $2.89 a$ & $2.0 \mathrm{TDZ}-7.00$ \\
\hline $\mathrm{TDZ}+5 \% \mathrm{CM}$ & 0.28 & $3.39 a$ & 0.56 & 1.33 & $2.94 a$ & $2.0 \mathrm{TDZ}-5.67$ \\
\hline
\end{tabular}

The means of frequency of occurrence for various degrees of scales of primordia labelled with the letter $a$ in each row are the highest and statistically not different at least at the $\alpha=0.05$ level of significance. 
TABLE 4. Results of testing the independence by the $\chi^{2}$ test between combinations of BAP and/or TDZ and degrees of scales of shoot primordia with respect to frequency of occurrence.

\begin{tabular}{|c|c|c|c|c|}
\hline \multirow{2}{*}{ No. } & \multirow{2}{*}{ Hypothesis of independence between two classification criteria in $\mathrm{r} \times \mathrm{c}$ contingency table } & \multicolumn{3}{|c|}{$\chi^{2}$ value for genotypes } \\
\hline & & Skrzeszowicka & Caroll A10 & Strain 175 \\
\hline 1. & $\begin{array}{l}4 \times 5 \text { contingency table: } \\
\text { combinations with }[\mathrm{BAP}, \mathrm{BAP}+5 \% \mathrm{CM}, \mathrm{BAP}+10 \% \mathrm{CM}, \mathrm{BAP}+15 \% \mathrm{CM}] \text { and scales } \\
\text { of shoot primordia }[0-4]\end{array}$ & $48.413^{* * *}$ & $30.635^{\text {** }}$ & $47.624^{* *}$ \\
\hline 2. & $\begin{array}{l}4 \times 5 \text { contingency table: } \\
\text { combinations with }[\mathrm{TDZ}, \mathrm{TDZ}+5 \% \mathrm{CM}, \mathrm{TDZ}+10 \% \mathrm{CM}, \mathrm{TDZ}+15 \% \mathrm{CM}] \text { and scales } \\
\text { of shoot primordia }[0-4]\end{array}$ & $39.402^{* *}$ & 9.266 & $37.299^{* *}$ \\
\hline 3. & $\begin{array}{l}2 \times 5 \text { contingency table: } \\
\text { combinations with }[\mathrm{BAP}, \mathrm{TDZ}] \text { and scales of shoot primordia }[0-4]\end{array}$ & 5.825 & 9.012 & $18.496^{* *}$ \\
\hline 4. & $\begin{array}{l}2 \times 5 \text { contingency table: } \\
\text { combinations with }[\mathrm{BAP}+5 \% \mathrm{CM}, \mathrm{TDZ}+5 \% \mathrm{CM}] \text { and scales of shoot primordia }[0-4]\end{array}$ & $22.794^{* * *}$ & $12.537^{*}$ & 6.167 \\
\hline 5. & $\begin{array}{l}2 \times 5 \text { contingency table: } \\
\text { combinations with }[\mathrm{BAP}+10 \% \mathrm{CM}, \mathrm{TDZ}+10 \% \mathrm{CM}] \text { and scales of shoot primordia }[0-4]\end{array}$ & 5.288 & 4.178 & $18.017^{* * *}$ \\
\hline 6. & $\begin{array}{l}2 \times 5 \text { contingency table: } \\
\text { combinations with }[\mathrm{BAP}+15 \% \mathrm{CM}, \mathrm{TDZ}+15 \% \mathrm{CM}] \text { and scales of shoot primordia }[0-4]\end{array}$ & $18.793^{* * *}$ & 0.317 & $16.440^{* * *}$ \\
\hline
\end{tabular}

tion were not rejected at the 0.05 level of significance. It means that location of the explants in root did not have significant influence on the number of regenerated shoots (Table 4). Despite that, the significant effect of explant position in root on the number of regenerated shoots was statistically not shown, the differences were visually observed. On the explant derived from proximal part of root (first three explants from root-shoot junction) the number of regenerated shoots was higher than on explants originated from distal part of root.

Effect of short term treatment of TDZ and CPPU on explant morphogenic response

Twelve hours incubation of explants in the liquid medium supplemented with TDZ resulted in callus proliferation and shoot formation. In the media containing 2.0 mg.dcm ${ }^{-3}$ and $10.0 \mathrm{mg} . \mathrm{dcm}^{-3} \mathrm{TDZ}, 25 \%$ and $73 \%$ of explants regenerated shoots, respectively. For $24 \mathrm{hrs}$ period of $2.0 \mathrm{mg} . \mathrm{dcm}^{-3}$ treatment only $50 \%$ of explants proliferated callus and all the other explants only expanded their size. After $36 \mathrm{hrs}$ of explant incubation at the presence 2.0 mg.dcm ${ }^{-3} \mathrm{TDZ} 45 \%$ of explants regenerated shoots, $36 \%$ regenerated shoot primordia directly on the explants and $36 \%$ proliferated callus tissue only. Increasing TDZ concentration up to $10.0 \mathrm{mg} . \mathrm{dcm}^{-3}$ resulted in very rich callus tissue proliferation by the explants and only $18 \%$ and $12 \%$ of them were able to regenerate shoot primordia and to form shoots, respectively (Table 5).

In the presence of CPPU in concentration $2.0 \mathrm{mg}^{-\mathrm{dcm}^{-3}}$, the response of explants was only the enlargement of their size as a result of $12 \mathrm{hrs}$ pretreatment. The effect of CPPU increasing up to $10.0 \mathrm{mg} . \mathrm{dcm}^{-3}$ resulted in callus proliferation only by $25 \%$ of explants, next $8 \%$ of explants were capable for callus proliferation and shoot primordia regeneration. Primordia were directly regenerated by $16 \%$ of root explants and in the other $8 \%$ of explants shoot formation was observed.

TABLE 5. The effect of direct treatment of explants by TDZ and CPPU on process of shoot differentiation.

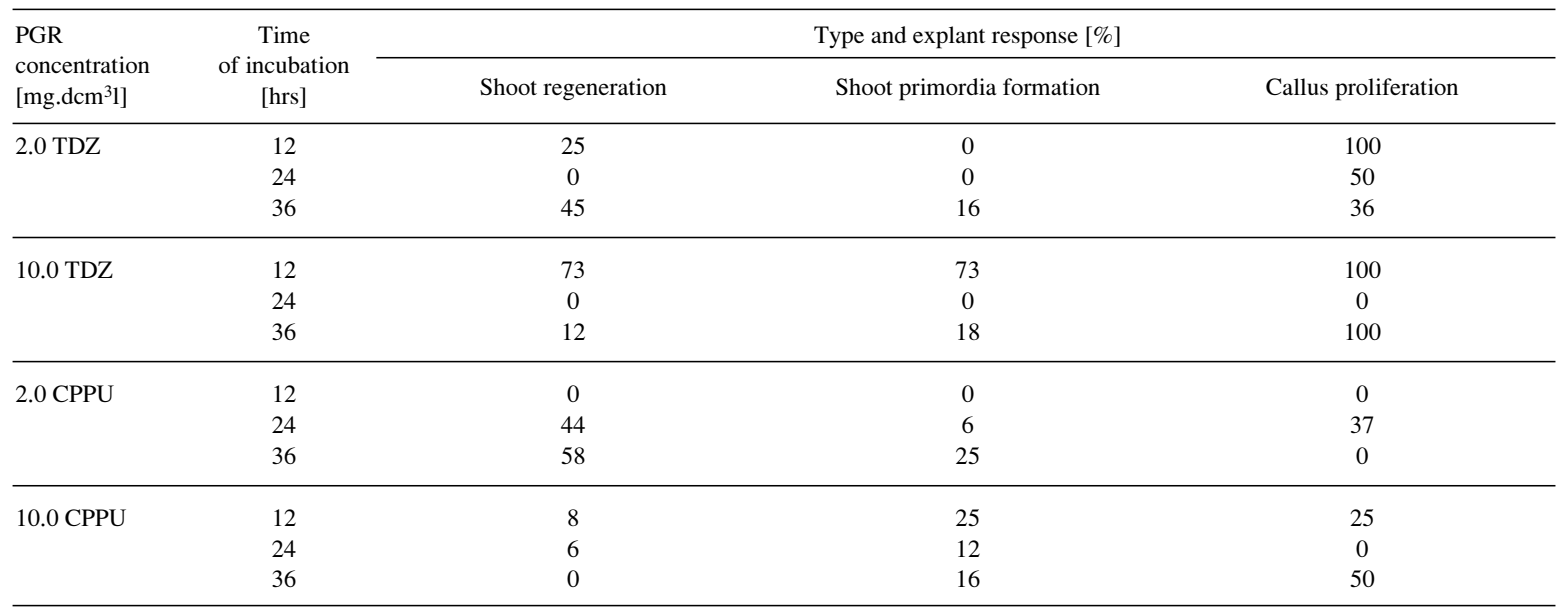


The extension of the time of the CPPU pre-treatment from $12 \mathrm{hrs}$ to $24 \mathrm{hrs}$ resulted in better morphological response of explants. $2.0 \mathrm{mg} . \mathrm{dcm}^{-3} \mathrm{CPPU}$ stimulated shoot formation by $44.0 \%$. Direct and indirect organogenesis was noticed for $71 \%$ and $29 \%$, respectively. The callus tissue proliferation concerned $37 \%$ of explants but $6 \%$ of explants were covered with shoot primordia. The effect of 10.0 mg.dcm ${ }^{-3}$ CPPU consisted in the expansion of explant size, but the shoot primordia and shoots were poorly regenerated by $12 \%$ and $6 \%$ of cultured explants, respectively.

The addition $12 \mathrm{hrs}$ of CPPU pre-treatment helped to recognize the increase of explants, showing high percent of the shoot primordia regeneration $(25 \%)$ and shoot formation $(58 \%)$ when medium was supplemented with 2.0 mg.dcm ${ }^{-3}$ CPPU. 36 hrs of CPPU treatment at the presence of $10.0 \mathrm{mg} . \mathrm{dcm}^{-3}$ induced $50 \%$ explants for callus proliferation. Only $16 \%$ of explants were able to form shoot primordia directly by explants.

\section{DISCUSSION}

In culture of Lotus corniculatus root seedling explants regenerated shoot primordia, shoots and callus tissue depending on the PGR and coconut milk combinations and concentration. On hormone-free medium shoot primordia and shoots were individually regenerated only on proximal end of explant. With increased medium complexity the explant polarity was reduced. SEM and cyto-histological analysis showed that primary cortex was the tissue of meristematic activity what resulted in shoot formation. The microscopic observations revealed, that during initial weeks of culture, callus tissue proliferation was more intensive on proximal than distal end of explant. Not only for birdsfood trefoil, primary cortex appeared to be the source of callus tissue proliferation, meristematic center formation and shoot regeneration (Zenkteler 1971; Shrivastava et al. 1985). The electronogram showing disrupted rhizodermis proves the meristematic activity of cells of the primary cortex of the studied by us genotypes. (Fig. 2c) There are numerous examples of different origin of embryogenic and organogenic tissue. Single cells of rhizodermis of Camellia japonica (Vieitz et al. 1991), Solanum tuberosum (Espinoza and Dodds 1985) or cells of pericycle of Brassica spp (Lazzeri and Dunwell 1984a, b) and Iris pseudocarpus (Laublin et al. 1991) constitute a proof of different tissue involvement in shoot regeneration from seedling root explants.

For better understanding the effect of explant position in root on its morphogenic potential and shoot differentiation, in our study the explants were divided into three groups: distal, central and proximal with three consecutive explants for each. The number of regenerated shoots was scored. For var. Skrzeszowicka and Caroll A10 the significant effect of media combinations on the number of regenerated shoots at the level of significance $a=0.01$ was ascertained. In the case of strain 175 the effect of the medium was significant at the level of significance $a=0.05$. However, the effect of explant location in the root on shoot formation was statistically not shown at both the levels of significance $\alpha=0.01$ and $\alpha=0.05$. As a consequence of different seedlings growth and development, various root lengths were observed, and sometimes the number of explants used in experiments was not the same. Such situation required to introduce an additional criterion of shoot regeneration in relation to explant position. All regenerated shoots of proximal, central and distal explants were summarised and statistically analyzed. The statistical analysis did not show significant differences between the number of formed shoots in relation to the explants position. It is necessary to stress that visual recognition of the morphogenic response showed a gradual decrease of the response in direction from proximal to distal end of root. Similarly, the amount of callus tissue was bigger on proximal then distal end, independently of the PGR concentrations. Such distribution of morphogenic potential was earlier described for other species (Burger and Hackett 1986), however, such species like Convonvulus arvensis and Chondrillia juncea did not follow the mentioned above type of response (Bonnet and Torrey 1965; Kefford and Caso 1972). To solve the problem of the relationship between the used plant growth hormones and the degree of scale of shoot primordia, with respect of the frequency of the occurrence, the hypothesis of independence was advanced. Regardless the plant growth hormones used, the frequency of the scale will be the same. In the case of rejection (**) of the hypothesis the effect of the frequency is significant. Table 4 shows that the studied genotypes were characterized by various dependence on the advanced hypotheses.

In short treatment experiments, from among the used concentrations of CPPU, $2.0 \mathrm{mg} . \mathrm{dcm}^{-3}$ had the significant effect on direct shoot differentiation. Callus tissue proliferation did not stop organogenesis and shoots were formed. We confirmed earlier described effect of TDZ on proliferation both callus and shoots. Short term TDZ and CPPU treatment had an important influence of the development of some explants. Unfortunately, we did not observe somatic embryo formation, what was earlier described for some other species.

In conclusion we would like to stress that the morphogenic potential of $L$. corniculatus observed in the field is expressed as early as seedling stage of plant development in vitro conditions. Root, as the more conservative part of the plant than shoot, with high morphogenic potential on its whole length could be explored for vegetative propagation of the species.

\section{LITERATURE CITED}

AHUJA P.S., HADIUZZAMAN S., DAVEY M.R., COCKING E.C. 1983. Prolific plant regeneration from protoplast-derived tissue of Lotus corniculatus L. (Bird's-foot trefoil). Plant Cell Rep. 2: 101-104.

BONNET H.T., TORREY J.G. 1965. Chemical control of organ formation in root segments of Convolvulus cultured in vitro. Plant Physiol. 40: 1228-1236.

BÖHMER P., MEYER B., JACOBSEN H.-J. 1995. Thidiazuroninduced high frequency of shoot induction and plant regeneration in protoplast derived pea callus. Plant Cell Rep. 15: 26-29 .

BURGER D.W., HACKETT W.P. 1986. Gradients of adventitious bud formation on excised epicotyl and root sections of $\mathrm{Ci}$ trus. Plant Science 43: 229-232.

DAMIANI F., MARIOTTI D., PEZZOTTI M., ARCIONI S. 1985. Variation among plants regenerated from tissue culture of Lotus corniculatus L. Z. Pflanzenzüchtung 94: 332-339.

ESPINOZA N.O., DODDS J.H. 1985. Adventitious shoot formation on cultured potato roots. Plant Science 41: 121-124. 
FELLMAN C.D., READ P.E., HOSIER M.A. 1987. Effect of thidiazuron and CPPU on meristem formation and shoot proliferation. Hort. Sci. 22: 1197-1200.

KEFFORD N.P., CASO O.H. 1972. Organ regeneration on excised roots of Chondrilla juncea and its chemical regulation. Austr. J. Biol. Sci. 25: 691-706.

LAUBLIN G., SAIN H.S., CAPADOCIA M. 1991. In vitro plant regeneration via somatic embryogenesis from root culture of rhizomatous irises. Plant Cell Tiss. Org. Cult. 27: 15-21.

LAZZERI P.A., DUNWELL P.A. 1984a. In vitro shoot regeneration from root segments of Brassica oleracea and B. napus cultivars. Ann. Bot. 54: 341-350.

LAZZERI P.A., DUNWELL P.A. 1984b. Establishment of isolated root cultures of Brassica and regeneration from cultures root of Brassica oleracea var. Italica. Ann. Bot. 54: 350-361.

MACLEAN N.L., GRANT W.F. 1987. Evaluation of bird's-foot trefoil (Lotus corniculatus) regenerated plants following in vitro selection for herbicide tolerance. Can. J. Bot. 65: 1275-1280.

MOHAMED F.M., READ P.F., COYNE D.P. 1992. Dark preconditioning, CPPU and thidiazuron promote shoot organogenesis on seedling node explants of common and faba beans. J. Am. Soc. Hort. Sci. 117: 668-672.

MOK M.C., MOK D.W.S., AMSTRONG D.J., SHUDO K., ISOGA Y., OKAMOTO, T. 1982. Cytokinin activity of N-phenylN'-1,2,3-Thiadiazol-5-urea (thidiazuron). Phytochemistry. 21: 1509-1511.

MURASHIGE T., SKOOG F. 1962. A revised medium for rapid growth and bioassays with tobacco tissue cultures. Physiol. Plantarum 15: 473-497.

MURTHY B.N.S., MURCH S.J., SAXENA K.P. 1995. Thidiazuron-induced somatic embryogenesis in intact seedling of peanut (Arachis hypogea L.): endogenous growth regulator levels and significance of cotyledons. Physiol. Plantarum 94: 268-276.

MURTHY B.N.S., SAXENA P.K. 1994. Somatic embryogenesis in peanut (Arachis hypogea L.) stimulation of direct differentiation of somatic embryos by four-chlorferuron (CPPU). Plant Cell Rep. 14: 154-150.

NIIZEKI M., SAITO K. 1986. Plant regeneration from protoplast of birdsfoot trefoil Lotus corniculatus L. Japan Journal of Breeding 36: 177-180
OKAMATO T., SHUDO K., TAKASHI S., YATSUNAM T., ISOGAI Y., YAMADA K. 1978. Shoot formation of tobacco callus by various cytokinin-active ureas and pyrimidines. Chem. Pharm. Bull. 26: 3250-3252.

ORSHINSKY B.R., TOMES D.T. 1985. Effect of long-term culture and low temperature incubation on plant regeneration from callus line of bird's-foot trefoil (Lotus corniculatus L.) J. Plant Physiol. 119: 389-397.

POFELIS S., LE H., GRANT W.F. 1992. The development of sulphonyl urea herbicide-resistant bird's-foot trefoil (Lotus corniculatus L.) plants from in vitro selection. TAG 83: 480-488.

RYBCZYŃSKI J.J., BADZIAN T. 1987. High regeneration potential of root segments of Lotus corniculatus L. seedlings on hormone - free media. Plant Sci. 51: 239-244.

RYBCZYŃSKI J.J., DĄBROWSKI L., BADZIAN T. 1995. Changes in morphogenic potential of shoot regeneration from root explant of Lotus corniculatus (L.) seedling. Acta Physiol. Plant. 17: 211-218.

SHRIVASTAVA P.S., STERNHAUSER A., GLOCK H. 1985. Plantlet differentiationin leaf and root cultures of birch (Betula pendula Roth.). Plant Sci. 42: 209-214.

SWANSON E.B., TOMES T.D. 1980. Plant regeneration from cell cultures of Lotus corniculatus and the selection and characterisation of 2,4-D tolerant cell lines. Can. J. Bot. 58: 1205-1209.

TAKAHASHI S., SHUDO K., OKAMATO T., YAMADA K., ISOGAI Y. 1978. Cytokinin activity of N-phenyl-N'-(4pirydil)urea derivatives. Phytochemistry 17: 1201-1207.

TEGEDER M., GEBHARDT D., SCHIEDER O., PICARDT T. 1995. Thidiazuron-induced plant regeneration from protoplast of Vicia faba cv. Mythos. Plant Cell Rep. 15: 164-169.

THOMAS J.C., KATTERMAN F.R. 1986. Cytokinin activity induced by thidiazuron. Plant Physiol. 81: 681-683.

VEITZ A.M., SAN-JOSÉ C., VIEITEA F.J., BALLESTER A 1991. Somatic embryogenesis from roots of Camellia japonica plantlets cultured in vitro. J. Am. Soc. Hort. Sci. 116: 753-757.

ZAR J.Z. 1984. Biostatistical analysis. Prentice-Hall International Inc.

ZENKTELER M. 1971. Development of new plants from leaves and roots of Atropa belladonna L. in the in vitro culture. Acta Soc. Bot. Pol. 40: 305-313. 